УДК 317.774

\title{
УКРАЇНА В ПОРЯДКУ ДЕННОМУ «NЕWSWЕЕК» У ПЕРШОМУ КВАРТАЛІ 2014 РОКУ
}

\author{
Ірина Саківська \\ Украӥнський католицький університет, \\ вул. Іларіона Свєниіцького, 17, 79000, Львів, Украӥна \\ e-mail: sakivska@ucu.edu.ua \\ https://orcid.org/0000-0003-4463-5983
}

Світова преса широко висвітлювала події на Майдані у Києві та початок збройного нападу Росії на Україну. Аналіз контенту онлайн-версії провідного американського тижневика «Newsweek» щодо цих подій дозволяє побачити розгортання війни Росії проти України, показати, як ці публікації формують «порядок денний» щодо подій в Україні.

Ключові слова: інфопривід, порядок денний, праймінг, фреймінг, друковані масмедіа, преса США, контент аналіз, мас-медіа і суспільство, комунікаційні ефекти.

Постановка проблеми. Згідно із дослідженнями формування порядку денного в американських медіа є ряд журналів та газет із репутацією, яка дозволяє їм встановлювати порядок денний для усіх інших дрібніших медіумів, таким чином роблячи їх лідерами формування громадської думки на медійному ринку. Серед таких $\epsilon$ «Newsweek» - один із трьох найбільших ліберальних тижневиків у США [5, с. 911].

Формування порядку денного - це підбір тем для висвітлення, які вартують уваги читачів. Основна ідея порядку денного полягає в тому, що медіа відвертим чином впливають громадську думку. Таким чином що частіше певний інформаційний привід згадується у мас-медіа, то важливішим він видається його аудиторії [4].

Висвітлення міжнародних новин має функцію встановлення порядку денного у певній країні. У даній статті нас цікавить не так перший рівень порядку денного (праймінг), як другий, менш очевидний рівень - фреймінг, коли фокус дослідження зміщується 3, власне, висвітлення інфоприводу на висвітлення атрибутів цих інфоприводів, тобто важливим бачиться не лише сам факт приділення уваги Україні у іноземній пресі, як такий, а фокус на тому, що саме «Newsweek» пропонує своїм читачам думати про Україну [17, с. 367]. Актуальність запропонованого дослідження полягає в необхідності досліджень визначення механізмів встановлення порядку денного в США - засобами найвпливовішої американської преси. В цьому полягає й новизна нашого дослідження.

Мета публікащіï. У запропонованій статті ми спробуємо проаналізувати встановлення порядку денного щодо подій в Україні від січня до березня 2014-го року в

(с) Саківська I., 2019

Наукове рецензування і рекомендація до друку - проф. Набитович I. 
американській пресі - на прикладі онлайн-версії журналу «Newsweek». При цьому ставимо такі завдання: ми намагатимемося дослідити, наскільки частими були згадки про Україну у цій газеті в означений період; означити й проінтерпретувати, які головні фрейми формують образ подій в Україні у означений період; продемонструвати на теплокарті детальні «спалахи активності» частки згадувань подій в Україні в цьому часописі за перший квартал 2014 року.

Аналіз останніх досліджень. Окремі аспекти контент-моніторингу й контент-аналізу публікацій в американській пресі щодо подій 2014-го і наступних років на сторінках закордонних видань розглядалися в роботах С. Дзюби [19], О. Консевич [20], С. Польовик [21], Галини Піскорської та Н. Яковенко [22]. Однак у цих публікаціях імідж України у сформульованій в нашій статті проблеми майже не заторкнуто.

Єдиною публікацією про встановлення порядку денного подій в Україні в американській пресі є наше дослідження (на прикладі онлайн-версії газети «Тһе Washington Post» від січня до березня 2014-го року) [19].

У онлайн-версії журналу «Newsweek» за 2014 рік ми зафіксували 289 заміток, статей і репортажів, присвячених Україні. Ми згрупували всі згадки по датах публікації та відобразили на теплокарті (анг. - heatmap). Теплокарта - це спосіб графічного опису даних, при якому значення, відображені у матриці, відрізняються за допомогою кольорів. Теплокарти - це досить новий спосіб візуалізації даних. Водночас iз іншими графічними методами, теплокарта є синтезом різних методів візуалізації даних [18, с. 183].

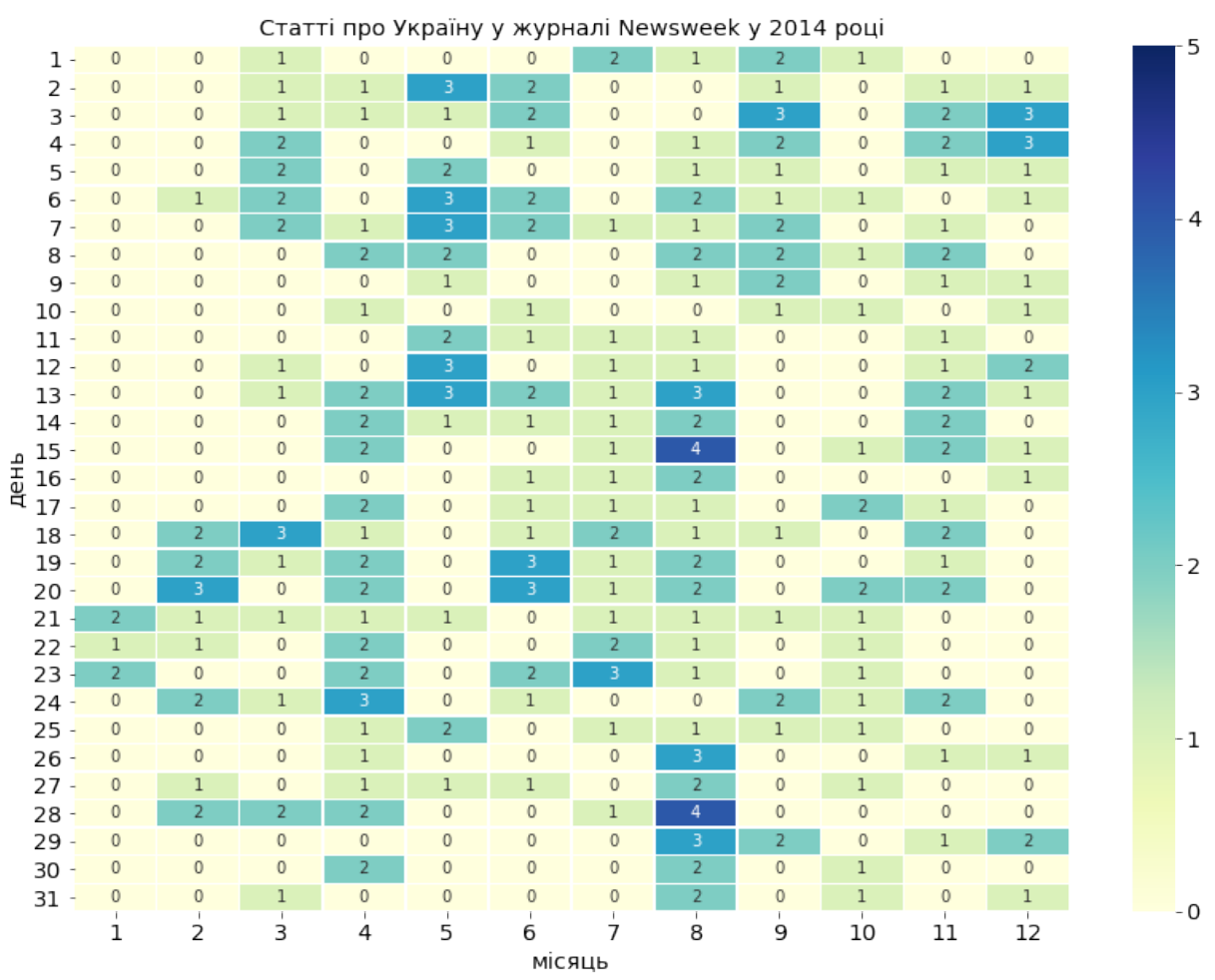


Незважаючи на те, що у цьому дослідженні ми детально розглянули лише перших три місяці 2014 року, на теплокарті ми згрупували усі дані за рік відносно місяця по осі Х та дня місяця по осі Ү. На теплокарті можна детально побачити «спалахи активності» у квітні, місяці активної фази кризи на Донбасі, травні та серпні. Досить велика частка згадувань припадає на березень, вересень і листопад 2014. Хоча збільшення кількості публікацій спостерігаємо 3 початком розстрілів демонстрантів на Майдані.

У перший місяць 2014 року інтерес до України був ще досить низьким, оскільки про Україну в «Newsweek» вийшло лише 5 матеріалів і всі вони, згідно з нашою теплокартою, датовані 21-23 січня (у порівнянні із серпнем 2014 року, коли про Україну знаходимо аж 48 згадок). У ці дні, як ми знаємо, відбулися перші криваві сутички на Майдані Незалежності, що спричинили смерті протестувальників. Водночас до цього про Україну в «Newsweek» згадували лише декілька разів за рік. Згідно з нашими результатами пошуку, в 2008 році про Україну вийшло лише 3 матеріали, у 2009 році 4, у 2010 році було 6 статей про Україну, ще по 2 статті вийшло в 2011 і 2013 роках.

Перший репортаж вийшов 21 січня (під заголовком «Обмежені можливості президента України, поки протести набирають силу»). Текст підсумовує останні події на Майдані, наголошуючи, що: «Незважаючи на два місяці заворушень після відміни торговельної угоди з Свропейським Союзом і наближення до Росії, нічого не віщує, що 63-річний колишній будівельник (тобто Янукович. - I. C.) перебуває під загрозою усунення від влади» [1]. Водночас «Newsweek» робить припущення, що варіантів виходу із ситуації у Януковича залишається не так уже й багато, оскільки вуличне протистояння його владі стає все більш інтенсивним після помилок у політиці, як от прийняття законодавства, яке забороняє практично будь-яку форму антиурядових протестів. Тут же вони подають цитату незалежного аналітика з Центру прикладних політичних досліджень «Пента» Володимира Фесенка: «Ці закони були найбільшою помилкою Януковича цього року» [1].

У репортажі використовується емоційно забарвлена лексика, спрямована на краще розуміння ситуації американськими читачами, яка водночас створює певні фрейми у сприйнятті інформації: «жостоке поводження поліції із студентами-протестувальниками»; «драконячі закони проти громадських протестів», «президент повернувся спиною до компромісу». Водночас «Newsweek» прямим текстом пише, що «його (президента) рейтинги популярності впали 3 початку кризи в листопаді, і будь-які більш серйозні помилки у вирішенні питань серйозно загрожуватимуть його шансам отримати другий термін повноважень у лютому 2015 року» [1].

У репортажі (під заголовком «Президент України зустрівся з опозицією після смерті трьох під час зіткнень») за 22 січня «Newsweek» відразу цитує прем'єр-міністра Миколу Азарова, який назвав антиурядових протестувальників «терористами», а також подає його цитату, де він каже: «Я офіційно заявляю, що це злочинці, які повинні відповідати за свої дії» [16].

Тут же М. Азаров заявив, що міліція не має вогнепальної зброї, а міністерство внутрішніх справ нібито спростувало наклепи, що поліція використовувала зброю під час заворушень. «Newsweek» констатує, що хоча сотні людей продовжують мирний протест у таборі на Майдані Незалежності, проте є група радикалів, яка закидує поліцію «коктейлями молотова» та бруківкою. Поліція відповідає гумовими кулями, шумовими гранатами і сльозоточивим газом [16]. 
Також у січні «Newsweek» приділив увагу ситуації, коли в інтернеті з'явився ролик, як Беркут знущається з чоловіка, роздягнувши його до гола (М. Гаврилюка - I. C.), із посиланням на сайт «Української правди», нагадуючи, що в день, коли знімали відео температура повітря була -10 градусів Цельсія (14 градусів за Фаренгайтом). Проте цю ж новину вони «збалансовують» згадкою про Президента і його діiі, а також поліцію, яка теж страждає у сутичках: «За час насильницьких зіткнень в центрі Києва загинули три учасники мітингу, понад 150 силовиків поранені. Президент України Віктор Янукович призначив позачергове зібрання парламенту для припинення насильницьких заворушень» [14].

У лютому 2014 року в «Newsweek» вийшло всього 15 згадок про Україну, більшість із них поміж 18 і 24 лютого, коли на Майдані незалежності відбувалися масові заворушення із десятками смертей і сотнями поранень протестувальників. Уже із самих заголовків читачі «Newsweek» мали б розуміти хронологію подій: «Зафіксовано декілька смертей після наступу Беркуту проти протестів, що вже тривають декілька місяців в Україні»; «Захід введе санкції щодо України»; «Янукович підштовхнув переворот»; «Оновлення в реальному часі: кількість смертей в Україні зростає через насильство»; «СС прагне до миру, коли в Україні кількість смертей перевищила 75»; «В Україні підписано мирну угоду, це відкриває шлях до ранніх виборів»; «Верховна Рада України скинула президента, який після «перевороту» втікає з Києва»; «Український президент-втікач оголошений у розшук за масові вбивства»; «Озброєні чоловіки захопили два аеропорти в Криму»; «Янукович знову з’являється в Москві»; «Путін використовує українську революцію, щоб спробувати відібрати Крим».

У репортажі за 18 лютого з Майдану Незалежності «Newsweek» пише: «Це був найкривавіший день від коли колишня радянська республіка, що опинилася в геополітичній боротьбі між Росією та Заходом, здобула незалежність». Водночас нижче, цитуючи оператора Reuters, вербально візуалізуються події на Майдані для кращого розуміння авдиторії, що ж насправді відбувалося в Україні: «Навколо дим від вибухів наметів, що палають, купи шин і деревини, коли тисячі демонстрантів трималися в центрі площі. Також запалали кілька поверхів будівлі профспілок, які використовувалися як антиурядові штаби» [13].

Позицію європейської спільноти «Newsweek» вербалізує через висловлювання Комісара СС з питань розширення Штефана Фюле, який повідомив, що він розмовляв із прем'єр міністром і той гарантував, що влада намагатиметься уникнути використання вогнепальної зброї на Майдані. Водночас додає не дуже оптимістичне: «Заради українців і заради майбутнього цієї країни, я буду молитися, щоб він мав рацію» [13].

Також знаходимо пояснення ролі Росії у заворушеннях: «Беркут прибув (на Майдан) через кілька годин після того, як Москва надала Україні 2 мільярди доларів допомоги для підтримки економіки. Цю допомогу вона довго затримувала, вимагаючи рішучих дій для придушення протестів». Водночас подається ширша картина ставлення Росії до ситуації: «Відновлення пакету допомоги на суму 15 млрд. доларів - це сигнал, що Росія вважає, що Янукович має план припинити протести і відмовився від будь-якої ідеї приведення лідерів опозиції до влади» [13].

Водночас «Newsweek» робить припущення, у якому чітко зафреймлено симпатію до України: «Хоча, здається, президент Росії Владімір Путін зараз виграв битву 
за вплив в Україні, протестувальники, які зайняли центр столиці, так просто не здадуться» [13].

У репортажі за 20 лютого у гіперпосиланні вказано 50 загиблих, проте у заголовку йдеться уже про 75 жертв. Вони підтверджують кількість вбитих словами міністра охорони здоров'я, кажучи, що це означає, що лише в четвер загинуло 47 учасників протесту. Тут «Newsweek» знову повторюється, зауважуючи, що це було, безумовно, найгіршим насильством з того часу, як Україна постала з розвалин Радянського Союзу 22 роки тому [3].

Тут же вони продовжують у репортажному стилі, що: «Лише за три години запеклої боротьби на Майдані незалежності, неподалік від того місця, де Президент Віктор Янукович зустрічався з делегацією СС, на землі лежало понад 20 вбитих мирних жителів», а також описують виступ на телебаченні Міністра внутрішніх справ Віталія Захарченка, який, будучи одягненим у камуфляж, заявив, що: «Поліція отримала бойове озброєння і буде використовувати його «у відповідності до закону» для захисту себе або звільнення своїх 67 колег, що перебувають у полоні» [3].

Водночас із подіями на Майдані, у лютому 2014 у світі відбувалася інша велика міжнародна подія - олімпійські ігри у російському Сочі. Новина, що частина української збірної відмовилася виступати і обурилася забороною одягнути чорні пов'язки в знак жалоби, теж потрапила у топ новин за 20 лютого в «Newsweek»: «Представники української команди хвилиною мовчання вшанували пам’ять жертв. На прапори України на балконах їхньої будівлі в олімпійському селі почепили чорні стрічки» [11].

У суботу 22 лютого вийшов інший репортаж, під заголовком «Верховна Рада України знімає президента, який втікає з Києва через «переворот»«. У ньому читачам у деталях розповідають про голосування українського парламенту з метою усунення Президента В. Януковича із посади та його втечу до Pociï [12]. «Newsweek» каже, що: «Незворотне повалення проросійського лідера після кровопролиття в Києві, в якому загинуло 82 людей, а центр столиці перетворився на пекло, повинно витягнути Україну з орбіти Москви і направити у бік Свропи [12]. Самому ж Януковичу «Newsweek» теж надає слово, кажучи, що він засудив те, що він називає «переворотом» після тижня бойових дій на вулицях столиці, а рішення парламенту «нелегальним» [12].

А уже 24 лютого у репортажі «Президента-втікача розшукують за масове вбивство» $з$ особою Януковича ніхто не церемониться, на відміну від січневих матеріалів. «Newsweek» пише: «Нова українська влада видала у понеділок ордер на арешт за масові вбивства Президента Віктора Януковича. Він переховується після того, як його режим повалили криваві вуличні протести, в яких поліцейські снайпери вбивали опозиційних демонстрантів». Також «Newsweek» цитує допис з Фейсбук-сторінки А. Авакова, де він пише, що на В. Януковича відкрито справу про масові вбивства мирних жителів [15].

Підсумовують тему краху правління Януковича, «Newsweek» робить однозначні висновки, не залишаючи читачам простору для іншого погляду на ситуацію в Україні: «Це був ганебний політичний кінець для Януковича; його публічно покинули найближчі союзники, він втратив свою розкішну резиденцію під Києвом, а також став свідком звільнення з в'язниці головної його суперниці Юлії Тимошенко» [15].

Цикл статей, присвячених подіям Революції Гідності, завершується детальним описом ситуації на Майдані: «Настрій серед декількох сотень на площі був сумішшю втоми, скорботи за понад 80 убитими минулого тижня, і почуття перемоги після 
трьох місяців протестів» [15]. «Newsweek» подає детальний опис сцени на Майдані і великий екран, на якому одне за одним показують обличчя тих, хто загинув. Щоб краще передати атмосферу на Майдані «Newsweek» підкріплює репортаж цитатами українців, які брали участь у революції, як от одягненого у чорну уніформу Григорія Кузнєцова: «Зараз не час для святкування. Ми все ще перебуваємо у стані війни. Ми залишатимемось тут так довго, як нам доведеться» чи слова Галини Кравчук, жінки середнього віку з гвоздикою у руках: «Зараз ми шукаємо Європу. У нас є надія. Ми хочемо приєднатися до Європи» [15].

Водночас «Newsweek» переводить фокус своїх читачів із Майдану на Схід i Південь України, зауважуючи, що: «Сутички у Криму і деяких східних містах між прихильниками нового порядку в Києві і тих, хто прагне залишитися поруч з Москвою, розбурхали страх сепаратизму. Тиждень тому ці проблеми були зосереджені на Заході, де українські націоналісти відмовилися від Януковича і проголосили самоврядування» [15].

Незважаючи на те, що подій лютого відбувалися в Україні і безпосереднього стосунку до Росії вони не мали, проте «Newsweek» досить багато уваги приділяє й реакції Кремля: «Втеча Януковича залишила Путіна біля розбитого корита, в той день, коли він сподівався, що очі будуть на величному фіналі Сочинської Олімпіади» [15].

«Newsweek» також цитує прем’єр-міністра Росії Дмітрія Мєдвєдєва щодо російського бачення ситуації в Україні: «Ми не розуміємо, що там відбувається. Існує реальна загроза для наших інтересів і для життя наших громадян», нагадуючи, що цими ж словами, посилаючись на обов'язок захищати своїх громадян, у 2008 році Кремль обгрунтовував своє військове втручання у Грузії, підтримуючи сепаратистів у Південній Осетії [15].

«Newsweek» наближає інтерес читачів до подій в Україні через ставлення американської сторони. Вони пишуть, що: «Підкреслюючи несхвалення Вашингтоном того як Україна справляється $з$ протестами, посольство США в Києві заявило, що скасувало візи ряду українців, пов'язаних з насильством з боку силовиків проти демонстрантів у листопаді та грудні [2013 року]» [16].

Водночас, цитуючи Радницю з національної безпеки президента Барака Обами С’юзан Райс, часопис акцентує на тому, що американський уряд вважає, що Росія не наважиться ввести війська на територію України: «Це була б серйозна помилка. Не в інтересах України чи Росії, чи Європи, чи Сполучених Штатів бачити розкол країни» [15].

Проте «Newsweek» відверто транслює ставлення до України у висловлюванні про те, що Сполучені Штати і їх союзники в НАТО не будуть ризикувати, щоб вступити у пряму військовою конфронтацію з Росією. Водночас наголошують, що «Відгомони холодної війни підкреслюють високі ставки в Україні, чиї 46 мільйонів людей і широко розкинута територія опинилися в геополітичному перетягуванні каната» [15].

Згідно 3 нашою теплокартою, у березні 2014 року в «Newsweek» вийшло 22 статті про Україну, пік уваги припав на перший тиждень місяця, коли Росія окупувала Крим, провівши фіктивний референдум, та середину місяця (18-24 березня), коли російські війська захопили українські військові бази.

Головною темою місяця стало вторгнення російських військ на кримський півострів. У той час, коли в українських медіа російські війська все ще називали «зеле- 
ними чоловічками», «Newsweek» напряму пов’язував ситуацію із В. Путіним: «Україна мобілізована для війни, і Вашингтон погрожує економічно ізолювати Росію у найбільшому протистоянні Москви із Заходом після холодної війни - після того, як президент Владімір Путін заявив, що має право вторгнутися до свого сусіда» [10].

Матеріалом за 1 березня 2014 року під назвою «Російський президент Путін стверджує, що має право на вторгнення в Україну», «Newsweek» почав цикл детальних та ілюстративних репортажів з Кримського півострова, де розпочався збройний конфлікт між Україною і Росією.

«Війська без відзнак на уніформі, але явно російські (а деякі у транспортних засобах з російськими номерними знаками) вже захопили Крим, ізольований півострів у Чорному морі, де Москва має велику військову присутність у штабі Чорноморського флоту. Нова влади Києва була безсила їх зупинити». - розповідає про ескалацію конфлікту «Newsweek» [8].

«У самому Криму прихід військових викликав захоплення у проросійської більшості. У прибережному місті Балаклава, де російськомовні війська в броньованих машинах з чорними російськими номерними знаками оточували невеликий гарнізон українських прикордонників, сім’ї ставали до фотографії з солдатами, а весільні кортежі із захопленням сигналили на знак привітання», - у стилі художнього репортажу продовжує «Newsweek» оповідати історію захоплення українського Криму [8].

Тут же знаходимо продовження у стилі художнього репортажу «блокбастера» для американської аудиторії: «Російські війська зміцнили свій контроль над Кримом, а в суботу неспокій поширився на інші регіони України. Проросійські демонстранти влаштували жорстокі сутички з прихильниками нової влади України й підняли російський прапор над урядовими будівлями в кількох містах» [8].

Також Росія влаштувала військові маневри 3 150-ма тисячами військовослужбовців нагромаджених уздовж сухопутного кордону України. Київ підтвердив, що Росія направила сотні своїх громадян через кордон для проведення протестів [10]. Водночас Путін заперечив, що російські збройні сили безпосередньо були задіяні в безкровному захопленні Криму, заявивши, що військовослужбовці в уніформі без національних знаків були «силами самооборони» [6].

Актові підняття прапора, як маркування простору, «Newsweek» надає особливого значення. Це згадується у декілька інших репортажах із Криму, а згодом і Донбасу: «Демонстранти встановили російські прапори на урядових будівлях у Харкові, Донецьку, Одесі та Дніпропетровську [8].

«Newsweek» розповідає, як у Донецьку, рідному регіоні Януковича, місцеві посадовці заявили, що хочуть референдуму щодо статусу регіону. «Ми не визнаємо владу в Києві, вони не є легітимними», - цитують слова голови протесту Павла Губарєва зі сцени в Донецьку. Тисячі послідовників, тримаючи гігантський російський прапор і скандуючи «Росія, Росія!», пройшли до донецької облдержадміністрації і, здерши український прапор, почепили російський [8].

«Newsweek» також повідомляв, що у російських мас-медіа події в Україні висвітлюються зовсім не так, як в українських та західних медіа. Усунення Януковича зображають як державний переворот, організований небезпечними екстремістами, що фінансуються Заходом, а також що не виглядає на те, що хтось 3 росіян висловлює незгоду з таким перекрученим висвітленням [10]. 
«Newsweek» робить передбачення щодо майбутньої геополітичної ситуації в Україні на основі доказів присутності російських військ у Криму, що потенційно більшим ризиком буде поширення конфлікту на решту України, адже, на їх думку, у цьому випадку населенню буде важко обрати на чиїй вони стороні. «У напрузі, що панувала в суботу, демонстрації іноді перетворювалися на насильство у містах на Сході, де більшість людей, які хоча і є українцями, - російськомовні та багато хто підтримує Москву і Януковича» [8].

Окрім висвітлення російської сторони «української кризи», читачів «Newsweek» також повідомляють й про офіційну позицію України та Заходу у цьому питанні. «Прем’ер-міністр Арсеній Яценюк, голова уряду, що прийшов до влади після того, як московський спільник Віктор Янукович втік тиждень тому, заявив, що російські військові дії будуть початком війни і закінченням будь-яких відносин між Україною i Росією» [8]. «Це навіть не погроза: це фактично оголошення війни моїй країні» [10].

«Незважаючи на те, що Міністерству оборони було наказано здійснити виклик резервів, що теоретично означало б усіх чоловіків до 40 років, але Україні буде важко намагалася знайти додаткову зброю або уніформу для значної їх кількості», - розповідає «Newsweek» ситуацію із обороноздатністю України на початку військового конфлікту з Росією. Часопис доповнює, що українське військо слабке і не може рівнятися до свого сусіда. Міжнародний інститут стратегічних досліджень Великобританії оцінює, що Київ має менше ніж 130000 військовослужбовців із озброєнням, літаки ледве готові до польотів, а єдиний підводний човен має невелику кількість запасних деталей [10].

Для контрасту «Newsweek» порівнює боєготовність Росії, кажучи, що Путін витратив мільярди доларів, щоб оновити і модернізувати можливості збройних сил після розпаду Радянського Союзу. Спеціальні підрозділи Москви зараз вважаються одними із найкращих у світі [10].

Безумовно, читачів «Newsweek» цікавить, чому новини про війну в Україні потрапляють до їхнього порядку денного, а також потенційна участь американської сторони у цьому конфлікті. Практично у кожному репортажі присвяченому ситуації в бачимо роль та реакцію Сполучених Штатів Америки.

«Newsweek» розповідає у деталях, як Державний секретар США Джон Керрі здійснив свій перший візит до Києва з моменту повалення підтриманого Росією президента Віктора Януковича, описавши цей досвід як «зворушливий, сумний i надихаючий». «Керрі поклав квіти на Майдані Незалежності до меморіалу прозахідних демонстрантів, убитих поліцією в минулому місяці, зустрівся з тимчасовими лідерами країни і оголосив про надання економічного пакету на 1 мільярд доларів і технічну допомогу новому уряду» [6].

«Newsweek» також цитує Президента США Барака Обаму, який заявив, що референдум в Криму про приєднання до Росії порушує міжнародне право і що американські санкції будуть спрямовані на покарання Москви за втручання в Україну [2].

Але водночас не всі так схвально відреагували на надання допомоги Україні. До прикладу Майк Роджерс, голова Комітету Палати розвідки під час огляду звітів розвідки США про Україну запропонував з обережністю ставитися до того, як саме Америка втручається в ситуацію: «Я б, звичайно, запропонував тренінгові пакети, щоб вони (українці) могли зрозуміти які існують загрози контррозвідки, а також запропонував би поради щодо того, як має виглядати програма боротьби з повстанцями» [9]. 
Скептичні настрої, щодо гучних заяви про надання Україні фінансування та військової підтримки та економічних санкцій проти Росії також можна знайти у частині репортажів за березень. До прикладу: «Аналітики вважають, що економічні санкції США, швидше за все, матимуть незначний вплив на Росію, якщо вони не супроводжуватимуться потужними заходами великих європейських держав, які мають більш глибокі торговельні зв’язки з Москвою і залежать від російського газу» [9].

Проте, відзначає «Newsweek», реакція Заходу в значній мірі є лише символічною. Обама та інші лідери призупинили підготовку до саміту G8 в Сочі, де Путін тільки що завершив проведення своїх зимових Олімпійських ігор за 50 мільярдів доларів. Лише Велика Британія заявила, що їі міністри будуть триматися осторонь параолімпійських ігор, що пройдуть у Сочі [10].

Безумовно революція та війна в Україні глибоко стурбувала весь Західний світ, адже вона порушуває статус кво, у якому перебуває Європа уже понад пятдесят років. Ці віяння і реакції Заходу «Newsweek» передає у своїх репортажах про Україну: «Це, мабуть, найнебезпечніша ситуація в Європі після радянського вторгнення до Чехословаччини в 1968 році», - сказав західний чиновник на умовах анонімності. «Дійсно, ми повинні зважати на те, що Крим знаходиться у руках Росії. Сьогодні завдання полягає в тому, щоб утримати Росію від захоплення російськомовного сходу України» [8].

Висновки. Таким чином, ми розглянули встановлення порядку денного подій в Україні в першому кварталі 2014-го року на прикладі онлайн-версії газети «Newsweek». При цьому в публікації проведено фокусування на тому, які саме інформаційні меседжі пропонує «Newsweek» своїм читачам про події в Україні у період Революції Гідності.

Перспективи подальших досліджень. Перспективою досліджень є визначення головних фреймів, які формують образ подій в Україні в період подій на Майдані й розширення представлень на теплокарті детальних «спалахів активності» частки згадувань подій в Україні в американських медіа у 2014 році - році початку російської агресії проти України.

\section{REFERENCES}

1. As Protests Swell, Options Limited for Ukraine's President [Електронний ресурс]. Режим доступу : https://www.newsweek.com/protests-swell-options-limited-ukrainespresident-226678.

2. Crimea Votes to Join Russia, Accelerating Ukraine Crisis [Електронний ресурс]. Режим доступу : https://www.newsweek.com/crimea-votes-join-russia-acceleratingukraine-crisis-231139.

3. EU Seeks Peace as Ukraine Death Toll Hits 75 [Електронний ресурс]. - Режим доступу : https://www.newsweek.com/ukraine-truce-shattered-death-toll-tops-50-229615

4. McCombs M. The Agenda-Setting Function of Mass Media / Maxwell McCombs, Donald Shaw // Public Opinion Quarterly. 1972. Vol. 36 (summer). Pp. 176-187.

5. McCombs M. Shaping the Agenda of Local Daily Newspapers: A Methodology Merging the Agenda Setting and Community Structure Perspectives / Maxwell McCombs, Marcus Funk // Mass Communication and Society. 2011. Vol. 14 (6). Pp. 905-919. 
6. Putin: Military Force Would Be 'Last Resort' in Ukraine [Електронний ресурс]. - Peжим доступу : https://www.newsweek.com/putin-military-force-would-be-last-resortukraine-230876.

7. Russian Forces Storm Ukraine Base in Crimea, U.S. Sees 'Dark Path' to Isolation [Електронний ресурс]. - Режим доступу : https://www.newsweek.com/russianforces-storm-ukraine-base-crimea-us-sees-dark-path-isolation-232378.

8. Russia's Putin Claims Authority to Invade Ukraine [Електронний ресурс]. - Peжим доступу : https://www.newsweek.com/russias-putin-claims-authority-invadeukraine-230622.

9. Stein J. Intelligence Panel Chief Urges U.S. Aid for Ukraine / Jeff Stein [Електронний pecypc]. - Режим доступу : https://www.newsweek.com/intelligence-panel-chiefurges-us-aid-ukraine-231110

10. Ukraine Mobilizes After Putin's 'Declaration of War' [Електронний ресурс]. - Режим доступу : https://www.newsweek.com/ukraine-mobilizes-after-putins-declarationwar-230637.

11. Ukraine Olympic Team Members Leave Sochi in Support of Protesters [Електронний ресурс]. - Режим доступу : http://www.newsweek.com/ukraine-olympic-teammembers-leave-sochi-support-protesters-229738.

12. Ukraine Parliament Removes President, Who Flees Kiev in 'Coup [Електронний ресурс]. - Режим доступу : https://www.newsweek.com/ukraine-parliament-removespresident-who-flees-kiev-coup-229909.

13. Ukraine Police Charge Protesters After Nation's Bloodiest Day [Електронний ресурс]. - Режим доступу : http://www.newsweek.com/ukraine-police-chargeprotesters-after-nations-bloodiest-day-229401.

14. Ukrainian Riot Police Caught on Video Making Naked Man Stand in Snow, Taking Pictures [Електронний pecypc]. - Режим доступу : https://www.newsweek. $\mathrm{com} /$ ukrainian-riot-police-caught-video-making-naked-man-stand-snow-takingpictures-226890.

15. Ukraine's Fugitive President Wanted for Mass Murder [Електронний ресурс]. - Peжим доступу : https://www.newsweek.com/ukraines-fugitive-president-wanted-massmurder-230038.

16. Ukraine's President, Opposition Meet After Three Killed in Clashes [Електронний ресурс]. - Режим доступу : https://www.newsweek.com/ukraines-president-oppositionmeet-after-three-killed-clashes-226704.

17. Wanta W. Agenda Setting and International News : Media Influence on Public Perceptions of Foreign Nations / W. Wanta, G. Golan, C. Lee // Journalism \& Mass Communication Quarterly. 2004. No 81(2). Pp. 364-377.

18. Wilkinson Leland, Friendly Michael (2009). The History Of The Cluster Heat Map. The American Statistician. -2009 (May). Vol. 63. No 2. Pp. 178-185. [Електронний pecypc]. - Режим доступу : https://www.cs.uic.edu/ wilkinson/Publications/heatmap. pdf

19. Дзюба Є. Медіа-імідж України: українська проблематика в іноземних ЗМІ [Електронний ресурс] / Є. Дзюба. - Режим доступу : http://www.dialogs. Org.ua/ru/cross/ page1819.html.

20. Консевич О. Образ України у польському тижневику «Polityka» після Революції Гідності / О. Консевич // Грані. 2016. Вип. 15 (40). С. 118-136. 
21. Польовик С. Образ України на сторінках російських газет: контент-аналітичне дослідження / С. Польовик // Вісник Харківського національного університету імені В. Н. Каразіна. Серія «Соціальні комунікації», 2018. № 11. С. 35-40.

22. Піскорська Г. Імідж України в контексті російсько-українського конфлікту / Галина Піскорська, Наталія Яковенко // Міжнародні відносини. Серія: Політичні науки. 2015. № 5. С. 1-10.

23. Саківська I. Україна в порядку денному «The Washington Post» у першому кварталі 2014 року / Ірина Саківська // Spheres of Culture / Ed. by I. Nabytovych. Lublin, 2018. Vol. 17. Pp. 497-508.

\title{
UKRAINE IN «NEWSWEEK» AGENDA SETTING IN FIRST QUARTER OF 2014
}

\author{
Iryna Sakivska \\ Ukrainian Catholic University, \\ Ilariona Svetnsitskoho Street 17, 79000, Lviv, Ukraine \\ e-mail:sakivska@ucu.edu.ua \\ https://orcid.org/0000-0003-4463-5983
}

The world press widely covered the events on the Maidan in Kyiv and the beginning of the armed attack of the Russian Federation on Ukraine as well as the occupation of the Crimea. According to research on the formation of the agenda in American media, there are a number of reputable magazines and newspapers that allows them to set an agenda for all other smaller media, thus making them the leaders of public opinion in the media market. Among them is a «Newsweek» - one of the three largest liberal weekly magazine in the United States. Of course, the revolution and the war in Ukraine deeply disturbed the whole Western world, because it violates the status quo, which has been in Europe for over fifty years. These trends and reactions of the West the «Newsweek» reports in their articles about Ukraine.

The content analysis of the leading American press on this matter allows us to see the beginning and deployment of Russia's war against Ukraine (not just armed, but also media aka hybrid war), to show how these publications set the agenda in American press about the events in Ukraine, and hence, from the perspective of time, demonstrate how this media agenda begins to affect the political reaction to Russia's armed attack on Ukraine.

This is a perspective that we use to look into an agenda setting for events in Ukraine in the first quarter of 2014, using the example of the online version of the Newsweek magazine. At the same time, the publication is focused on what information messages and frames «Newsweek» offers to its readers about events in Ukraine during the period of the Revolution of Dignity.

The article analyzes how frequent and deep mentioning of Ukraine in this magazine was during the specified period; it is indicated and interpreted what main frames form the image of events in Ukraine during the specified period; a detailed «outbreak of activity» on the heatmap was shown on the example of the mentions of events in Ukraine in the magazine for the first quarter of 2014.

Key words: newsmaker, agenda setting, framing, priming, communication effects, print media, USA press, content analysis, media and society. 